This is the Author Original Manuscript of an article published by Taylor \& Francis in Quarterly Review of Film and Video on February 08 2018, available online: https://www.tandfonline.com/doi/full/10.1080/10509208.2017.1409097

Beyond the Screen, Beyond the Story: The Rhetorical Battery of Post-Classical films.

José Antonio Palao-Errando

Communication Sciences, Universitat Jaume I, Castellón, Spain

Antonio Loriguillo-López

Communication Sciences, Universitat Jaume I, Castellón, Spain

Teresa Sorolla-Romero

Communication Sciences, Universitat Jaume I, Castellón, Spain

Correspondence details

loriguil@uji.es

Departament de Ciències de la Comunicació

Facultat de Ciències Humanes i Socials

Universitat Jaume I

Av. Sos Baynat s/n

E-12071 Castelló de la Plana

Espanya (Spain) 


\section{Beyond the Screen, Beyond the Story: The Rhetorical Battery of Post-Classical films.}

This paper attempts to make a classification of some of the narrative and stylistic resources of the post-classical cinema in the age of the global screen through a minimal description of a battery of rhetorical resources present in some of the most relevant post classical films from the $90 \mathrm{~s}$. Specially, we focus on two main axis: the multi-screen cohabitation in the mise-en-scène and the increasing radicalization of complex narration.

Keywords: Narratology; Screen; Hyperframe; Hyperstory; Hipernucleus

\section{The Phenomenon and the Approach}

In the past few decades the mainstream cinema has found itself negotiating with all formats and devices for circulating audiovisual stories in the digital age. First came the DVD, but the journey has ended with the current transmedia and crossmedia conglomerates and in all forms of adaptation to the so-called 'pervasive media' formats (Dovey and Fleuriot). Cinematic discourse has continued to struggle to adapt and compete with these rival screens, hybridising itself with them and transforming its own texture. Along these lines, we can classify the transformations into two broad types. On one hand, the mise-en-scène and the concept of continuity have given rise to what we could call the hyperframe, in which the film screen is offered as a continuity receptacle for all the rival screens (computer, surveillance video, satellite images, etc.), transforming the entire classical conception of the mise-enabyme. On the other hand, in the narration itself, post-classical cinema opts to deconstruct narrative linearity and to deploy different plots and levels of action and representation, leading us to the notion of hyperstory. This paper attempts to make an exploration and 
classification of the resources of the new battery of rhetoric that the post-classical cinema constructs through these two concepts of hyperframe and hyperstory, giving rise to multiple figurative and narrative resources (hypernucleus, hypercatalysis (or pronuclear catalysis), ontology of continuity, multimedia syntagma, etc.) that provide radical transformations in contemporary cinema in a different direction to that taken by the avant-garde, cinematic modernity and experimental cinema, as the new resources are orientated reinforcing narrative greed rather than poetic-metaphorical connotations.

We have chosen to include these transformations under the heading of what is known as post-classical cinema, although, as most authors agree in pointing out, we can speak of recognisable post-classical features at least since the seventies (Thompson, Bordwell). However, the two notions we have referred to are also associated with the visual, narrative and information revolution of the digital age. This intermediary relationship ${ }^{1}$ is promoted by narrative transformations and a mise-en-scène that generates complex structures - the socalled puzzle films (Buckland) or puzzle pictures (Sterritt 478) - and the en abyme mise-enscène of the multi-screen and hyperfilm era (Lipovetsky and Serroy). Bolter and Grusin state that 'a medium in our culture can never operate in isolation, it always enters into relationships of respect and rivalry with other media' and also that the new media redesign and 'remediate' the older media. This leads them to theorise on the term hypermediation as opposed to media transparency:

Although each medium promises to reform its predecessors by offering a more immediate or authentic experience, the promise of reform inevitably leads us to become aware of the new medium as a medium. Thus, immediacy leads to hypermediacy. The process of remediation makes us aware that all media are at one

\footnotetext{
${ }^{1}$ See Young.
} 
level a "play of signs" [...]. At the same time, this process insists on the real, effective presence of media in our culture (19).

As we have already suggested, what we propose in this text is a catalogue of rhetorical resources implemented by the cinema of the $21^{\text {st }}$ century. Although the continual interdependence of some resources with others is clear, we have decided to classify them into these two blocks for reasons of methodological imperative and clarity of explanation. As for the corpus from which we will extract the examples, it is a varied one, because these transformations cover all contemporary cinema without distinctions or consideration of hierarchies. As Lipovetsky and Serroy say (67): '[i]n this sense, the concept of 'world cinema' has rightly been put forward, taking the form of a polished, sweetened transnational model.' Thomas Elsaesser goes into greater depths in this same concept when he explains that "Mind-game, played with movies" fits quite well a group of films I found myself increasingly intrigued by, not only because of their often weird details and the fact that they are brain-teasers as well as fun to watch, but also because they seemed to cross the usual boundaries of mainstream Hollywood, independent, auteur film and international art cinema' (13).

Eventually, it is a matter of exploring the relationship of film discourse with other audiovisual media from the perspective of Intermedia studies, but basing the research on textual analysis. In this flirtation of film with new media, we attempt to direct our research towards the effect of texts and discourses on this world by looking into the symbolic power of the sequential discourse of film compared to hypertextual discursive and interactive forms, on the hypothesis that the sequential allows dialectic projection and the effect of the construction of meaning on the world. As Francesco Casetti explains 'if it is true that superstimulation leads to a state of numbness, then hybrid energies serve to reactivate consciousness of a situation' (119). 
The aim of this text is not to make an in-depth analysis or hermeneutic of the films individually, but exclusively to establish a small catalog of narrative resources and mise-enscène.

\section{The Style of the Post-Classical Film Statement: Hyperframe}

\subsection{The Cinema Screen as Interpreter of Other Screens}

The post-classical cinema screen acts as host screen ${ }^{2}$ for all the other screens that populate our iconosphere, and it does so by offering itself as the factor for coordinating and integrating them ${ }^{3}$. The global screen age (Lipovetsky and Serroy) is characterised by the proliferation of ubiquitous media (Dovey and Fleuriot), where these devices have clearly been integrated into film stories as they have in our everyday lives. The cinema has joined in with this game in order to preserve its share in the entertainment business. Split screen (Hagener, Bizzocchi) is a very long-standing resource —we might think of Abel Gance's Napoleon (1927) - and it was omnipresent in the death throes of what is known as classical cinema in the sixties and seventies. However, both split screen and mise-en-abyme in general correspond, in this multiscreen context, to a different, strengthened ontology of continuity. As Bizzocchi states: '[t]his resurgence of the split-screen is supported by ongoing cultural changes in the production, distribution and reception of the moving image. The computer desktop, electronic games, television news, print comics and graphic novels have accustomed us to reading the many-windowed visual screen'. Films like Timecode (Mike Figgis, 2000) or

\footnotetext{
${ }^{2} \mathrm{We}$ are going to write all the terms we propose for identifying the resources integrated into the rhetorical code of post-classical cinema in italics. Although some are taken from traditional nomenclature accepted by the academic community, others, as will be seen, are our own and are intended to be a public proposal to that community.

${ }^{3}$ In audiovisual discourse, the screen that acts as the ultimate interface with the spectator, in that it includes within it other screens in a multimedia mise-en-abyme.
} 
The Rules of Attraction (Roger Avary 2002) have become exemplary cases of the current use of the resource in subsequent films such as Ocean's Thirteen (Steven Sodergergh, 2007), The Tracey Fragments (Bruce MacDonald, 2007), Scott Pilgrim vs. the World (Edgar Wright, 2010), 127 hours (Danny Boyle, 2010) or Nymphomaniac. Volume 1 (Lars von Trier 2013). But let us move on to explore other even more widespread procedures in modern cinema.

\subsection{Ontological Continuity}

Here, we are referring to a basic, structural resource in both film and television fiction, particularly in the action and crime genres. By ontology of continuity we understand the transcendence of the material point of view (enclosed by the geometry and economy of continuity) in providing meaning in the megageometry of the text, suggesting the absolute subordination of the (hypothetically pro-filmic) physical space to the audiovisual device through its Euclidian concept. There is, therefore, a material, empirical displacement of the point of view (the symbolic prosthesis by Bettetini) towards the meganarrative (episthemic prosthesis). This transcendence is not only an implicit (and therefore, banal) condition for the establishment of the model spectator of the Institutional Mode of Representation (from here on IMR; Burch), but also, depending on the intermedia power of attraction of the computer screen and the connivance with the post-classical spectator — who is much more familiar with the procedures for constructing audiovisual statements precisely on account of the new ICTs - it is constantly thematised as an essential narrative resource in the plot and deployed visually. Let us explore some case studies of the phenomenon.

\subsection{Image Analysis and the Induction Of Continuity}

Many forensic-themed films and series, epitomized by the CSI franchise where 'montage is an essential technique [...] for presenting complex processes of knowledge 
acquisition economically and stylishly' (Tasker 316), base their reconstructions on partial images which have some value in indicating the economy of continuity:

— In the episode \#3x08: Snuff, K. Fink, CBS: 2002 of CSI: Las Vegas ${ }^{4}$, the killer is discovered through the careful visual analysis of a violent, pornographic short film. In the production we see the deployment and coupling of various interfaces on the television screen. If we mention this case it is because it seems to be a pioneering one, but both the forensic theme and the use of scopic technologies in its service have become widespread both in television and film fiction e.g. Minority Report (Steven Spielberg, 2002), Taken (Pierre Morel, 2008), Fast Five (Justin Lin, 2011) or The Girl with the Dragon Tattoo (David Fincher, 2011).

- JFK (Oliver Stone, 1991) is developed around the reconstruction of the scene of the murder based on continuity with the Zapruder sequence, which is one of the first historical cases of the manipulation of film images as a heuristic procedure.

- Films in which the multimedia chase (see later on) is used constantly resort to the ontology of continuity for their reconstructions. For instance, Tony Scott's Enemy of the State (1998) and Déjà vu (2006) or Open Windows (Nacho Vigalondo, 2014). Even Titanic (James Cameron, 1997) openly thematises it.

\subsection{Editing as Principle of Reality}

The details of digital audiovisual logic are nowadays much more within the reach of general public than were the rhetorical techniques and principles of classical mechanical editing to its audience, and this promotes a transformation of the post-classical film. We can see this by looking at another emblematic film of the beginning of the millennium: Minority Report (Steven Spielberg, 2002).

\footnotetext{
${ }^{4}$ See Ortega, García Catalán and Palao-Errando.
} 
John Anderton (Tom Cruise) works with the greatest enthusiasm in a special brigade (Precrime) capable of preventing murders using three biological mutants (precogs) who can previsualise accurately in time and space and are capable of visually transmitting the perceptive virtual act. Supposedly, they are never wrong, so criminals can be arrested just before crimes are committed in order to prevent them. The process that makes these visions become legal acts is of great importance. In the opening sequence of the film, we see Anderton arriving at Precrime and we witness his modus operandi. When visions takes hold of the precogs, they start connecting to what they call the holosphere. Immediately, another device emits two wooden balls which begin to be engraved: they are going to give information about the victim and the killer. Meanwhile, Anderton stops the image and breaks it down into three frames. At the same time, his colleague looks in the different databases for the possible scene of the crime through the name of the murderer. Anderton continues to break down and recompose the image by digital means to find the place where the fatal sequence will happen, immersed in a set design of multiple, superimposed translucent frames. Amid these, his figure appears upright, acting as master of ceremonies and, at the same time, logic operator: he is the only guarantee of a coherent meaning for the puzzle. The subject who is going to be the focus of the film's narrative action manages to turn this jumble of unconnected images and data into an optical and figuratively acceptable image, perfectly subject to narrative logic and plausible diegesis. In other words, Anderton is editing a coherent audiovisual sequence. In fact, he finds the scene of the crime by straining the grammar of continuity - an image repeated from two different points of view but still compatible with the $180^{\circ}$ rule - indicating a merry-go-round near the scene of the crime: a piece of strictly audiovisual, Euclidian data making it possible to find it. We must therefore highlight four issues in Minority Report in terms of the version of digital screens offered by cinema as an institution: 
- The immediate way the precogs visions can be translated into audiovisual language: the perfect transmissibility of these acts of perception, even from the virtuality of their supposed neuronal plasticity. This assumes ontological faith in the image and the recording beyond all doubt.

- The flows of multiplexing find a good destination in the semio-rhetorical competence of a subject, in this case Anderton, assimilating them into the classical logic of the narrative image that sutures any original informative divide.

- But the substrate of this multiplexing is in the principle of the convergence of the database $^{5}$ and continuity: the miraculous arrival of the data at the interface at the same time as the multiplexed images (each from their own scene and generative logic) coincide in their vertices in a single sequence subject to the predominance of continuity, the audiovisual successor of the principle of excluded middle.

- The whole process of crime movie deduction has been replaced by the premonition, by the gestalt of editing and geometrical accuracy. Because the key to the thriller of the beginning of the century is the replacement of the deductive plot, in which all evidence owed a debt to its narrative assembly (motive, opportunity, criminal and concealment strategy) by the reign of iconic, irrefutable proof, to which the entire representational structure is subordinate. This occurs not only in a cinematic version, but also in the television crime genre, where the forensic theme has become dominant.

\subsection{The Continuity Error as Generic Feature}

In the first episode of Black Mirror (Charlie Brooker, Channel 4, Netflix: 2011-), the fictional prime minister's cabinet as well as the spectator are teased by the princess'

\footnotetext{
${ }^{5}$ For the assimilation of the Principle of the Database to the function of the linguistic paradigm, see Manovich. See also Elsaesser's observations.
} 
kidnapper, who sends a video in which he seems to be cutting a finger of the princess, from behind the chair where she is tied. Nevertheless, after he releases her and kills himself we will discover that he mutilated his own finger. The post-classical thriller very frequently uses the inverse procedure: a continuity error, normally discovered by means of digital analysis, shows fraudulent editing and points the way to the forensic truth beyond subjective determination. In other words, while continuity confirms reality as adaequatio, the continuity error reveals the truth as a mismatch between the film statement and the real scene. Some examples:

- In Minority Report, the fraudulent nature of Precrime is discovered because a continuity error is discovered in the editing of the sequence of the murder of the mother of the precogs. When Witwer (the federal inspector who has been sent to monitor Precrime) discovers that the attribution of the mother's murder to Agatha, the true origin of the conspiracy, has been a trick: the scene had been played twice, one detected by the precogs and the other interpreted as a simple 'echo' of the previous murder in the mutants' visions. This is unveiled by the detection of a very typical continuity error: in one of the 'takes' the wind moves the water on the lake in one direction and in the other in the opposite direction. Clearly, there were two 'shooting' times - two pro-filmic scenes - and the difference between them betrays the editing.

— In Contact (Robert Zemeckis, 1997), the only indication that the leading character's journey and encounter with the aliens has not been a hallucination is that the camera that accompanied her had recorded ' 18 hours of snow', although the terrestrial witnesses to her journey had lasted just a few seconds.

- In the Snuff episode of CSI: Las Vegas, the killer is discovered because of a continuity error checked by digital analysis of the film. In the take of the murder, the supposed actor is a few centimetres taller than in the previous take, exposing a switch. 
In fact, cinematic discourse itself provides us with the deconstruction of this film paradigm. In Mulholland Drive (David Lynch, 2001) ${ }^{6}$ we are offered a fiction divided between two worlds: the life of Betty as an aspiring actress who meets a dark-haired woman in trouble, and a second plot in which the roles are reversed (her protegée is her successful lover, actress and the fiancée of a well-known film director, while she is merely a second-rate failure). In the final scenes of the film, in which the ambivalent relationship between Diane/Betty's fantasies and her tough reality as a rejected lover are made clearer, all these poetics take the visual form of continuity error gazes (Diane's eyes see a reality subjectively betrayed by the change of shot) of movement and object (from a sofa assumed to be empty to the naked body of her lover Camilla; from a cup of coffee which, from one shot to another turns into a glass of whisky, together with a piano-shaped ashtray which had disappeared from its place in a previous sequence). All of these are highlighted by Lynch zooming in which makes them expand to fill the screen.

\subsection{Mise-En-Abyme $\boldsymbol{C}^{7}$}

By mise-en-abyme we mean any reframing inside a filmic enunciation which also serves as the external frame of reference. We can therefore establish two broad types:

1) Frame within a frame (provided the second frame is anisotopic): there is no need for it to belong to another diegetic level.

2) Story within a story.

We therefore have the following types of mise-en-abyme:

\footnotetext{
${ }^{6}$ For a detailed analysis of the film see Palao-Errando (2008).

${ }^{7} \mathrm{We}$ are giving a minimal series of notes because we do not think it is the purpose of this contribution to go into greater depth in the history and variants of the concept. See Moshe Ron.
} 
- Iconic mise-en-abyme: the reframing occurs visually inside the film screen, which we will call the host screen.

- Narrative mise-en-abyme (framed stories): the reframing can occur with various enunciative levels, it is not necessarily physical reframing.

- Diegitised mise-en-abyme: the most typical example would be the quoting of a picture, photograph or film frame which has given its visual shape to a natural shot in the diegetic plot of a film.

- Static mise-en-abyme: the reframed image is an image that does not contain movement (painting, photograph).

- Dynamic mise-en-abyme: the reframed image is a moving one (film, TV, infographic).

- Diegetically integrated mise-en-abyme: the reframed image has a narrative relationship with the diegetic line of the film. The clearest example is contemporary action cinema (see multimedia syntagma; or chase later on).

- Discursively integrated mise-en-abyme: one example might be metaphorical integration. In Blue (Krzysztof Kieslowski, 1993), some old people doing bungee jumping appear on the television that Julie's mother is watching. Another is historical or metanarrative integration. The most polished example would probably be Forrest Gump (Robert Zemeckis, 1994), in which all the historical or collective events referred to appear on the television screen (Palao-Errando 2009).

\subsection{From the Classic Mise-En-Abyme to the Intermedia Mise-En-Abyme}

This is the most genuine contribution of post-classical cinema to the varieties of miseen-abyme. Intermedia mise-en-abyme means the mixing of different textures and grains on the film screen, which may be the only trace of reframing if the reframed moving image comes to occupy the whole host screen. The basic difference from classic mise-en-abyme lies 
in the fact that the meta-representation is no longer necessarily concerned with a semantic gesture but rather with the (presumably innocuous) transparency of communicative utilitarianism. There are countless cases in post-classical cinema, beginning with the digital trickery of films like In the Line of Fire (Wolfgang Petersen, 1993) and Forrest Gump which put characters into places in the past where it is physically impossible to place the actor's body. But probably the most typical case is the appearance of the television set in cinematic fiction which-usually treats it as a mythical space for sclerotising the collective in the form of History or official information (Palao-Errando 2009).

Among the many examples we might mention - among which the title sequence of Dawn of the Dead (Zack Snyder, 2004) is especially suitable_-, it is worth highlighting the beginning of Munich (Steven Spielberg, 2005). The film tells of the attempts by Mossad at revenge for the attacks by Black September against the Israeli Olympic athletes at the 1972 Games. The whole plot is intended to show a diegetic attempt (individual Odyssey) to change a situation sclerotised on the television screen. In fact, the film begins with the attack itself, which moves in a few sequences from diegetic representation to being closed off in the television broadcast, shared as a global totem by all the audiences involved (Arabs, Israelis, Americans, who are the model audience for the film, and Germans), culminating in the private apartments of Golda Meir, where the revenge plan is hatched. In this case, the curved screens of paleotelevision contain a story — the attack — told with a mise-en-scène with a perfectly linear syntax, in which the action is followed by reframing the monitors while, at the same time, using this device to indicate the space-time location of each act of reception. Television is not, then, a theme of the story, but rather a simple indicator leading the film spectator into a position of globalised spectator who, due to the filmic representation, is accessing privileges the television viewer does not have. We even see masterful continuity 
between diegetic film shots and the television reframing, because even the terrorists themselves, and the hostages, are following the action on television.

\subsection{Multimedia Chase}

We understand a multimedia chase to be a chase sequence - recurring in the postclassical action film - which features images (shots) from various interfaces reframed on the film screen (e.g. infographics, documentary, electronic or satellite images, images from video surveillance cameras) and edited in continuity (continuity in abyme). This causes a multiplex effect restored and synthesised on the host screen, which acts as coordinator of all these sources, adjusting them according to conventional editing rules, independently of the narrative and enunciative level they come from. There are thousands of examples, but the ones appearing in the Bourne trilogy are very illustrative. Redacted (Brian de Palma, 2007) and the television series Modern Family (Steven Levitan and Christopher Lloyd, ABC, 2009) are, in fact, complete multimedia syntagmas.

Perhaps the most polished film of this genre in the nineties, and pioneer in many of its production, narrative and editing achievements, is Enemy of the State, which tells us of the vicissitudes suffered by civil rights lawyer Robert C. Dean (Will Smith). All the keys to the film appear presented in the trailer. It consists of a collage of images with digital travelling shots, overhead footage from surveillance cameras and shots taken from satellites. This proliferation of frames continues with night vision images, zoom lenses, monitoring rooms, and so on. The images capture antennae, police arrests and facilities being spied on. The view disseminated throughout the world updates its scenic essence. There is also an acceleration of the image typical of infographics or digital treatment, but the cinematic grain makes this coincide with normal speed, natural looking takes. Subliminally, the cinema offers itself as a non-alienated, anthropomorphic view compared with the other audiovisual media. 
But undoubtedly the film that best reflects the idea of a transmedia persecution, playing with the ontology of raccord through various iconic levels plastic and narrative, doing an exercise in deconstruction and irony of all them, is Open Windows (Nacho Vigalondo, 2014) in the magisterial sequence of the escape of the hotel (Palao-Errando 2015).

\subsection{The Shot/Reverse Shot Dialectic}

At this level of analysis, we highlight two functional dichotomies we have found in analysing post-classical films which have helped us to distinguish them conceptually from video art and experimental approaches.

- Diegetic or reactive reverse shot (IMR). This is the case of the sequential institutional grammar in which the dialectic between shots is entirely subject to the continuity rules and the principle of diegetic absorption. In this sense, the very dialectic of the reverse shot serves in the diegesis as the delegated point of view of the spectator, who is called on to identify with it. In fact, this is the level where transnational postclassical cinema is anchored in the gravitational field of the IMR. Kristin Thompson makes reference to it when she argues that in post-classical cinema flashbacks may be edited in a confused way but,

aside from the flashbacks, however, the scenes are handle in insistent shot/reverse shot. It's the stable system of classical storytelling that allows such "avant-garde" devices to be selectively assimilated. [...] Spectators are most likely to lose track of time, space, or the casual chain during the progression from one scene to another. This is one reason why the establishing shot is so crucial for maintaining a clear sense of locale. The most basic source of temporal and causal clarity is the dangling cause (19) 
In other words, it is at this level of film microenunciation where institutional coherence is guaranteed however confusing the plot may be. A good example of this is Inland Empire (David Lynch, 2006) ${ }^{8}$. Despite the intricacy of its plot what stops it moving away from the IMR (which would make it experimental or avant-garde) and maintains it as a deconstruction of the dominant model are those first shots of Laura Dern (playing either of the characters she plays in the film), whose surprised face suggests to spectators that their own surprise is not without reason.

- Analeptic reverse shot. In post-classical cinema we can find a reverse shot representing a diegetic or enunciative level different from the juxtaposed shot. It can also be included in the syntagmatic chain by direct cut, without any further enunciative mark than the transfer of the pro-filmic space denoting the leap in time. So, it can evoke a flashback without any other motivation than the meganarrative judgement itself. For instance, in The Social Network (David Fincher, 2010) the enunciation constantly resorts to these leaps in time, as in Blue Valentine (Derek Cianfrance, 2010).

- Proleptic (or hypothetical) reverse shot. A reverse shot can also refer to a hypothetical future which cannot be verified until it is later proved to be true. Next (Lee Tamahori, 2007) is entirely based on this procedure, both at intrasequential and macronarrative level.

- Metaleptic morphing. As a variant of metalepsis (see next section), the thoughts of the intradiegetic narrator (normally subconscious ones) may be metaphorised through visual changes achieved using digital technology (in other words, without changing the shot). It can be divided into two main types: in scenographic morphing the spectacular changes achieved take place in the set of the film itself. In Eternal Sunshine Of The Spotless Mind (Michel Gondry, 2004), the wiping of the leading character's memory is metaphorised by

\footnotetext{
${ }^{8}$ See the magnificent study by Cristina Álvarez.
} 
means of a scenographic change: buildings are ruined, lights go off, sudden changes of set, paradoxical time schemes (Stam, Porton and Goldsmith 229), innovative use of sound (Campora), etc. In Inception (Christopher Nolan, 2010), the manipulation of dreams by the leading characters take the form of spectacular changes of urban scenery. In The Tracey Fragments (Bruce McDonald, 2007) the imagination of the adolescent modifies, besides entire sequences, the real objects of the diégesis: in a magazine from a store she is seen as a famous rock star with the boy she likes as her boyfriend. In Paycheck (John Woo, 2003), the leading character's memories take the form of perfect audiovisual sequences collected on the computer screen. The whole The Matrix trilogy is plagued with metaleptic changes of set: the so-called bullet time is the most emblematic case. Another variant of metaleptic morphing would be the simple photographic trickery of inserting a figure absent from the record into a shot or photograph. We have already seen the examples of Forrest Gump and In The Line Of Fire.

\section{Hyperstory: the Structure of the Narrative Statement}

\subsection{The Story in Post-Classical Cinema}

We will move on, then, to deal with the macrostructural aspects of the post-classical film. In fact, one of the most striking phenomena in the whole world of cinema is the increasing complexity of narrative structures, both in shaping stories in which the plot overdetermines the story (the proliferation of non-linear narratives is its most obvious aspect) and in the presentation of heterogeneous universes within the fiction. Thomas Elsaesser gives a clear explanation:

There is clear evidence that cinematic storytelling has in general become more intricate, complex, unsettling, and this not only in the traditionally difficult categories of European auteur and art films, but right across the spectrum of 
mainstream cinema, event-movies/blockbusters, indie-films, not forgetting (HBOfinanced) television. Several of the features named as typical of the mind-game film are grist to the mill of professionally trained (literary) narratologists: single or multiple diegesis, unreliable narration and missing or unclaimed point-of-view shots, episodic or multi-stranded narratives, embedded or "nested" (story-withinstory/film-within-film) narratives, and frame-tales that reverse what is inside the frame (going back to The Cabinet of Dr Caligari [1919]). (19)

Earlier, he noted the main characteristics of this change, 'concentrating on the unreliable narrators, the multiple time-lines, unusual point of view structures, unmarked flashbacks, problems in focalization and perspectivism, unexpected causal reversals and narrative loops' (Elsaesser 18).

\subsection{Nucleus/Catalysis Dialectic (or Chatman's Satellite Action)}

As classical narratology based on Roland Barthes establishes, all actions making up a story can be divided into two main types:

- Nuclei. Actions that form the core structure of the story. They are characterised by opening and closing expectations and, therefore, they constitute irreversible nodes of the storyline.

- Catalyses. Subsidiary, peripheral actions that do not definitively change in the course of the story or anchor it in irreversible trajectories. They can be used to analyse an atmosphere, characterise a character, etc. The great hermeneutic relevance of catalyses is that they are the setting where the diegetic world is naturalised and legitimised.

Post-classical cinema, where the dislocation and non-linearity of the story takes on truly Baroque shades and where ellipsis and narrative economy (the need for a very rapid 
explanation and naturalisation of the features of the proposed diegetic universe) demands minimalist economy in all narrative resources, has been establishing new forms and categories within the nucleus-catalysis dialectic.

\subsection{Hypernucleus: Spaces of Contact Between Storylines}

With the rupture of linearity in post-classical films, the nucleus-catalysis distinction is, if not dissolved, at least weakened. Satellites (Chatman) do not exist if the linearity of the filmic syntax is broken because it is their discursive pregnancy what makes them relevant in the plot (because of the sequentiality resulting from the exact deconstruction of the linear plot), which here takes precedence over the story. As well as this, we notice the proliferation of parallel universes, in which narrative lines succeed one another on different, heterogeneous planes. In this way, new concepts emerge in the narrative rhetoric of post-classical films. The most outstanding is the hypernucleus: the point in space-time where all the storylines of a hypernarrative film (whether or not they are linear) coincide. It is a hypernarrative nucleus ${ }^{9}$ because it is the nucleus of various plots: it has multiple narrative valency. It is hyper because it links these plots and therefore has a semantic and metanarrative effect, a discursive effect. The hypernucleus is a catastrophic or turning point in the plot which discursively links several threads of the storyline that may be homodiegetic (belonging to the same world of fiction as in the films of González-Iñárritu) or heterodiegetic (David Lynch’s films).

We will therefore call hypernarrative space the point in a film in which two or more heterogeneous plots come into contact. These are not metanarratives: it is not a question of investigating or explaining their own fictionality as in art cinema or in the various approaches to modern cinema. Instead, it is the inescapable nucleus of the narrative that demands to be told (narrated, related). In this sense, the concept of hypernucleus would be intimately related

\footnotetext{
${ }^{9}$ Alissa Quart popularised the term "hyperlink cinema" in a review of Happy Endings (D. Ross, 2005).
} 
to the catastrophe or turning point of the topology. David Lynch's cinema is paradigmatic in the use of these hypernarrative spaces: the change of character/actor in Lost Highway (1997), the switching of contact spaces between the two parallel universes that sketch out Diane/Betty's frustration in Mulholland Drive (2001), or all the swaps between fictions in Inland Empire (2006). Also falling into this category would be that masterful macrotravelling shot that explodes the very narrative structure of a film like Atonement (Joe Wright, 2007). Ultimately the clearest symptom of the naturalisation of the hypernucleus and postclassical audiovisual narrative is the fact that the leading television series of recent years are built on this device. For example, Lost (J.J. Abrams, Jeffrey Lieber and Damon Lindelof, ABC, 2004-2010) or Leftovers (Damon Lindelof and Tom Perrota, HBO, 2014-), where 'the Island' or the world incident triggering the plot respectively are real hypernuclear spacetimes.

The narrative hypernucleus can, and usually do, consist of an accident — see the three films by González-Iñárritu: Amores perros (1999), 21 Gramos (2003), Babel (2006)—. The centre of gravity of the story in non-linear hypernuclear films that present polyperspectival narration (Stam, Porton and Goldsmith 257) is not diegetically premotivated, in contrast to the perfect diegetic motivation of a conventional films, as we will see when we talk about pronuclear catalysis and the pronucleus. But that implies a very particular, relevant kind of filmic treatment, particularly when it is presented (shot) several times. In these cases, the transubstantiation (transcendence) of the material point of view towards the provision of meaning in the megageometry of the text and the change of point of view involve a change in the economy of the information and revelation, which also provides textual consistency for polydiegetic films. Some examples:

- The telephone call between Morocco and San Diego that opens and closes the polyphonic (Bruns 2008) Babel, offered, in each case, from one side of the telephone line. 
- The various projections of the crash (or choque, Thakkar 11) that brings all the leading characters together in Amores perros.

- The various projections of objects and names between the two worlds in Mulholland Drive.

- The different takes of the reading of the script in Inland Empire, where we see different views of the scene through the eyes of Laura Dern, depending on whether she is playing one character or the other.

- The sequence of the murder of Melquiades in The Three Burials Of Melquiades Estrada (Tommy Lee Jones, 2005)

In a way, through the device of ontological continuity, we move from the material, empirical point of view (the symbolic prosthesis) to the meganarrative (epistemic prosthesis). This occurs in such a way that the various perspectives of the hypernucleus do not constitute a Cubist view, because they develop different diegetic lines and not diverse points of view of the same plot. Think of a completely different treatment to the kind of reiteration and denial that lead to a different conception of the filmic actions prevent us call these sequences true hypernuclei:

- In Vantage Point (Pete travis, 2008), the three parts of The Disappearance of Eleanor Rigby (Ned Benson, 2013-2014) or the TV series The Affair (Sarah Treem and Hagai Levi, Showtime, 2014-) each different point of view involves a radical change of story, not a different angle which can maintain continuity with the previous ones.

- In Groundhog Day (Harold Ramis, 1993), Source Code (Duncan Jones, 2011) or Edge of Tomorrow (Doug Liman, 2014) ${ }^{10}$ the repetition of the nucleus involves changes to it due to the fact that the leading character retains a memory and has learned from previous events.

\footnotetext{
${ }^{10}$ See more in Loriguillo-López and Sorolla-Romero.
} 
- In Next, however, the spectator is affected by the ambiguity of whether she is looking at a real event or the leading character's proleptic view, just as in Atonement or in the horror film Oculus (Mike Flanagan, 2013), where the reiteration of the events usually shows up the central character's tendentious visions.

In the cases we have just seen, the semantic effects of this return to a narrative unit when the spectator already knows the result have narrative effects, because they can appear to violate the nuclear nature of these units and make them subsidiary by removing their pregnant irreversibility. However, we believe that spectators consider them as nuclei because they know the expectations that have been closed off after this action. What semantic effect does this have? Undoubtedly diverting the economy of the story to the economy of meaning, towards the demand of a hermeneutic act beyond the metonymic-narrative decoding which we will deal with later under the concept of metalepsis.

We also find two other subsidiary narrative devices in the area of hypernarrative:

- We will call a sequence a subhypernucleus when it brings together two or more narrative lines of a whole hypernarrative film. It is a narrative (topological) category in time and space because it shapes both of the style of the shot (pro-filmic space, grain, lighting, etc.) and the editing. The subhypernucleus can be:

- Monodiegetic. The two narrative lines belong to the same diegetic universe. This is the case of a plot that includes two (or more) subplots narrated in parallel. This happens in the films of González-Iñárritu, the Three Colours trilogy directed by Krzysztof Kieslowski and Pulp Fiction (Quentin Tarantino, 1994). In general, many post-classical chase sequences may by hypernuclear or subhypernuclear rather than simply nuclear. 
- Polydiegetic: the diegetic worlds from which both strands come are heterogeneous. We can speak, for example, of an interdiegetic or hypernarrative space (sequence), e.g. Lost Highway, Mulholland Drive and Inland Empire.

- We suggest the term pronucleus for a very widespread narrative device in the postclassical thriller: a sequence unleashed by the story which very often represents a traumatic scene, typical of films based on a storyline where the main character's amnesia, a common feature in recent years. The causes are varied and can range from a ghostly memory, like the reiterative shot of the flame in Wild At Heart (David Lynch, 1990), to those underwater fragments in a film as spurious as I, Robot (Alex Proyas, 2004), the suitcase on a conveyor belt that opens White (Krysztof Kieslowski, 1994) or the traumatic scene where the protagonist loses his memory in the Bourne Trilogy. These are images, normally fragments taken from a supposedly incomplete sequence which appear to have no motive but which the spectator must asign, are strongly motivating. The approach of these films - the challenge to the spectator- consists of seeking their diegetic motivations, that is, the nuclear origin of the current state, usually presented in medias res.

An excellent example would be the TV series Flashforward (Brannon Braga and David S. Goyer, ABC, 2009-2010) which combines the hypernucleus (the general fainting, in which the whole world has had a prophetic vision) with the pronucleus, which would be the particular flashforward of Mark Bendford, the central character in the series, as all this involves composing the mosaic of the notice board in his office as he saw it when he fainted. The curious thing are the micro-mosaics: all the visions coincide with perfect continuity between the people who were seen together in their flashforwards. It is the conventional shot/reverse shot mechanic and the undoubted ontology of continuity. 
Another resource very characteristic of post-classical cinema in relation to polydiegetic and hypernuclear dynamics would be what we might call the inclusive parallelalternate syntagma; a procedure very common in hypernarrative films in which there are various levels of story in a relationship of hierarchical inclusion: for example the different dream levels in Inception or the two worlds of Matrix.

\subsection{Hypercatalysis (or Pro-Nuclear Catalysis)}

Just as we have spoken of the hypernucleus, we can speak of hypercatalysis, the function assumed by catalysis in post-classical cinema. We have already said that catalysis have the function of naturalising and legitimising the diegetic universe offered by the film. But a new, although not entirely unprecedented formula, repeated ad nauseam in postclassical cinema, is the truly anticipatory (proleptic) use of a feature of the fiction through catalytic presentation so that it is entirely believable when it subsequently appears as the nuclei. Kristin Thompson offers us the basis of this common procedure in Hollywood films:

The most basic principle of the Hollywood cinema is that narrative should consist of a chain of causes and effects that is easy to spectator follow [...] Unity and clarity demand that everything in the film should be motivated, whether in advance or in retrospect; that is, each event, object, character trait, and other narrative component should be justified, explicitly or implicitly, by other elements in the film. The lack of such justification is commonly referred to by Hollywood practitioners as a "hole" $(10-12)$

A very good example of this principle is The Man Who Knew Too Much (Alfred Hitchcock, 1956). The orchestra that appears in the film trailer as a purely decorative anticipation ends up triggering the nucleus of the film. Also, the song Che Será, presented as 
a catalyst and as a simple characteriological indication of the characters on their first night in the hotel in Marrakesh will play a nuclear role in the embassy. Even the taxidermist's error is a (spectacular) irony of the nucleus-catalyst relationship and the linearity of the story. However, while the resource is classical in origin (the dramatic principle of Chekhov's gun), its presence is overwhelming in all post-classical commercial action film. Some simple examples whose banality demonstrates how spectacularly widespread the procedure is:

- The Matrix. The first chase of the rebel ship in which only the real physical world is involved and which has no nuclear narrative consequence and the second, which is then polydiegetic hypernuclear (including the physical and the virtual space, as Neo is in the ship and the disconnection procedure to flee from the pursuing ships would kill him in the Matrix) and which is essential for the dénouement of the plot.

- In Next we are shown a conversation between two FBI agents while the one leading the investigation (Julianne Moore) is doing a shooting exercise. The great marksmanship she shows there appears again and is decisive for the dénouement of the story.

- And, in fact, a film like The Butterfly Effect (Eric Bress and John Mckye Gruber, 2004), in which the leading character has the capacity to change the past at will, which has its consequences in the present, is entirely based on spectators' familiarity with this resource.

\subsection{From the Classical (Homodiegetic) Flashback to the Post-Classical (Metaleptic) Flashback}

Another feature very characteristic of post-classical cinema, which is so fond of its temporal jumps and dislocation, is the reference of the flashback to the sphere of the discourse, more specifically mega-narrative ${ }^{11}$. The non-linear context favours the presence of the mega-narrator, 'an agency (the dream's "architect") that manipulates their [the

\footnotetext{
${ }^{11}$ See Gaudreault and Jost and Gómez Tarín (2009)
} 
characters'] experience -in the same way that the narration manipulates our own as viewers' (Poulaki 37), absolutely responsible for the plot. The first consequence is the move from the diegetised flashback, focused on a character's memories and perfectly contained and marked in the (classical) filmic discourse to the temporal jump depending exclusively on the narration. There can even be a dissolution of the difference between flashforward and flashback in the film, although such dissolution in medias res, is usually resolved by means of the IMR at the end of post-classical plots, at least in mainstream cinema. Examples would be the majority of the films of González-Iñárritu or Tarantino, or films such as Arrival (Denis Villeneuve, 2016) and some much more commercial ones such as Duplicity (Tony Gilroy, 2009). In summary, it is clear that the undiegetised temporal leap involves the arbitrary projection (semantic intentionality) of the plot over the story, with which we attribute its responsibility to the mega-narrator or implicit author of the film in a hermeneutic demand, which is why we have described these temporal leaps as metaleptic.

\subsection{Metalepsis}

As Gérard Genette explains, metalepsis, in principle, would simply be a variant of the metonymy that explains what follows by what precedes or vice versa. But it has become accepted with a more technical, restricted meaning involving the figure of the author in the causality of the fiction; in other words, naming the author as executor of the acts or events he narrates. For example: 'Shakespeare kills Romeo and Juliet at the end of his drama.' This device is particularly useful in non-linear (post-classical) narratives, as the non-causal reorganisation of the events related grants the mega-narrator/implied author a special leading role as the person specifically responsible for the discursive organisation of the story, in contrast to diegetic absorption. As Eleftheria Thanouli states: 
The idea that a narrator should be identified only when the filmmaker possesses a well-established artistic persona that intervenes in the filmic text was rightfully faced with fierce criticism from the part of the theorists who underlined that the concept of the narrator was logically and pragmatically indispensable for all fiction films, regardless of their production values or their institutional setting [...] At a very general level, the activity of a narrator is a prerequisite for a film text to come into being and to acquire a certain narrative form. Every film presents a fictional world comprising both visual and aural information that has been carefully selected and arranged by someone. (75)

It is precisely the metaphor that tends to seek the support of statements to sustain it. And the narrative dislocation invites us, as spectators, to think of the text poetically more than narratively ${ }^{12}$. The distribution of knowledge would therefore be as follows:

- Character: 0

- Spectator: -1

- Meganarrator: +1 (more knowledge).

In fact, as the IMR is a tendentially prosaic model (which overdetermines the paradigmatic axis for the syntagma; in other words, reducing the capacity for diction and choice), the subject of the statement is veiled by the demonstrative fluidity of the story. The metonymic/realistic narration system models: it is not a hermeneutic process for interpreting

${ }^{12}$ We intend to pay special attention to this relationship between poetics and narrative in post-classical films, and above all in non-linear tests, in the last part of our study. Our hypothesis is that there is an inescapable 'real narrative' in these stories, but we think that the very flirtation with poetic text and the demarcation between poetic subject and meganarrator can throw a great deal of light on the nature of non-linear post-classical narratives. 
the world. It follows that the obstinate appearance of a real nucleus in the dislocated story assumes a tendency towards the poetic; in other words towards being the question for the subject forming the statement beyond diegesis. For this reason we speak of pro-duction poetics (poiesis), which bring the story before the spectator (pro-ducere).

\section{Classicism and Post-Classicism: Cinema as the Interface that makes sense.}

The strongest advocates of the idea that classical cinema is absolutely alive in postclassical cinema are Thompson and Bordwell. Bordwell explains it clearly, using the concept of intensified continuity:

What has changed, $[\ldots]$ is not the stylistic system of classical filmmaking but rather certain technical devices functioning within that system. The new devices very often serve the traditional purposes. The new devices I'll be considering don't on the whole challenge this system; they revise it. Far from rejecting traditional continuity in the name of fragmentation and incoherence, the new style amounts to an intensification of established techniques. Intensified continuity is traditional continuity amped up, raised to a higher pitch of emphasis. It is the dominant style of American mass-audience films today. (119-120)

However, we believe that it is a widespread opinion that all the visual and narrative displays and innovations of post-classical action cinema only serve to promote greater visual and narrative spectacle and are not truly experimental in character. Post-classical cinema never breaks the sacred laws of the IMR and narrative linearity and causality (even narratively non-linear films like those of González-Iñárritu, Nolan or Tarantino, so abundant in this period, can be re-edited into a linear story). Meanwhile, the laws of continuity and editing, although these are taken to the limit, never reveal the truth of their support for the 
statement, instead, in each case, they invoke of the figure of the meganarrator as is formulated by Gaudreault and Jost. Although the concept of meganarrator has not enjoyed of a wide popularity among English-speaking film theory, its use is specially convenient as it comprises one key aspect for film narration which the literary-based implied author (Kind and Müller 64, Gómez Tarín 46), does not: the ocularization. This is very different from showing the traces of the subject of the statement, because that would be unconscious support that could invoke the position of the spectator as being responsible and constructing the meanings offered by the film. By contrast, the meganarratoris a figure who offers the spectator hermeneutic shelter and ensures the ultimate consistency of the narrative universe. It is true, then, that post-classical cinema deconstructs — while, in the majority of cases, reaffirming - the IMR, but what it never does is exclude itself from its gravitational field. We could define experimental cinema as that in which the spectator lacks a representative (a support, a link) in the filmic text, in which the grammar of continuity — of movement or, above all of shot/reverse shot- is overthrown as the principle of orientation and comprehension. In experimental cinema (not in art cinema, which is a deviation anchored in the IMR) there is no vicarious presence. This has hermeutic consequences for intelligibility, understanding and the affirmation of the causal logic of the story ${ }^{13}$.

What is happening in this post-classical digital age is that cinema is not mimicking, it is counterattacking. Narrative non-linearity is not so much an influence of digital narratives as a brake on their interactivity (Palao-Errando 2008). The cinema, as the host screen, is postulated as an interface of meaning, in contrast to other screens which it offers to host but which are considered to be entirely informative, denotative, and incapable of generating meaning alone.

\footnotetext{
${ }^{13}$ The voice off (for example in the first person or the timeless present) can play this role of the reverse shot as a vicarious presence.
} 
An example will help us to understand this. In Enemy of the State, after the multimedia chase affecting the principal characters, one of the agents complains, in front of the editing screen, that the linear view of the satellite camera prevents him seeing the character's face. The visual, aesthetic and narrative response to this failing was given eight years later by Tony Scott himself, in his film Déjà $V u$ (2006). After a bloody terrorist attack on a ferry in New Orleans, ATF agent Doug Carling (Denzel Washington) becomes involved in investigating the appearance of the body of Claire Kuchever on the bank of the river, as her death raises doubts as to whether it was the result of the same attack. Through the FBI, he contacts an experimental group that has managed to link the images from many satellites and is capable of offering an image synthesising what has happened in any given place in the forty-eight hours before the time of the request. Of course, they are investigating the attack on the ferry, but the problem is that they don't know where to look. That is why they need Carling. He suggests that they focus on Claire's house. The search sequence begins with overhead images from the satellites, which spectators now identify and regularly use, in a zoom, with successive match cuts in the axis, getting close to the required coordinates. Along with Carling, the spectator is astonished when, on reaching the required point, the system is not only capable of changing its axis of its view and moving to a frontal, ground level shot, but also of going through the walls into Claire Kuchever's house — which also, of course, has a roof - with perfect frontal shots. This is the demand of the ASN agent in Enemy of the State: perspective, the horizon of the view, transgressed and at the service of scopic propulsion. And what device is there powerful enough to perform this task if it is not the cinema image itself, the symbolic prosthesis (Bettetini) that allows the spectator to penetrate any hidden corner of the filmic space and shows itself to be the only interface capable of fitting the world's laws of construction into a frame with meaning and acceptance through the multiplexing of all information. Accuracy is nothing unless it is accompanied by meaning. 
And meaning, for the standard cinematic spectacle, is, above all, a sustainable emotion; a systematic image within a coherent story. The cinematic sequence is offered as a container for the logic of the world tied to the logic of the spirit. Later we find out that Carling really was looking at the past and that the Euclidian logic of the continuity was involved. That is why, as his colleague tells him from the present of the investigation, his fingerprints were all over the house, and the supposed mise-en-abyme of the digital and cinema screens was really a very classical reverse shot, the inception of amorous passion. In fact, what the team of scientists have discovered is not a way of coordinating images from multiple sources and channels in a systematic sequence but rather a wormhole making it possible for Carling to travel into the past to prevent the attack and save his lover. This will make the victory of the reality of love over the imagination of time possible and acceptable in the narrative acrobatics of a performative flashback, but with impeccable narrative coherence. After multiplexing after the division of the view by the multiplicity of electronic screens - the cinema screen is offered as the only interface capable of containing meaning.

\section{References}

Álvarez, Cristina. "Paisajes para el nuevo milenio: identidades esquivas, realidades en flujo y experiencias virtuales 2.b David Lynch: Inland Empire," Banda Aparte 7 (2008): 283296.

Barthes, Roland, and Duisit, Lionel. "An Introduction to the Structural Analysis of Narrative,” New Literary History, 6.2 (1975): 237-272.

Bettetini, Gianfranco. La conversación audiovisual: Problemas de la enunciación filmica y televisiva. Madrid: Cátedra, 1984.

Bizzocchi, Jim. The Fragmented Frame: The Poetics of the Split-Screen. Boston: Massachusets Intitute of Technology, 2009 Web. 
Buckland, Warren. Puzzle Films: Complex Storytelling In Contemporary Cinema. Oxford: John Willey \& Sons, 2009.

Burch, Noël. El tragaluz del infinito. Madrid: Cátedra, 1987.

Burns, John. "The polyphonic film," New review of Film and Television Studies, 6.2 (2008): 189-212.

Campora, Matthew. "Art cinema and New Hollywood: multiform narrative and sonic metalepsis in Eternal Sunshine of the Spotless Mind," New review of Film and Television Studies, 7.2 (2009): 119-131.

Casetti, Francesco. The Lumière Galaxy: Seven Key Words for the Cinema to Come. New York: Columbia University Press, 2015.

Chatman, Seymour. Story and Discourse: Narrative Structure in Fiction Film. Ithaca: Cornell University Press, 1978.

Dovey, Jonathan and Fleuriot, Constance. "La estética de los medios omnipresentes," adComunica 2 (2011): 63-80.

Gaudreault, André and Jost, François. El relato cinematográfico. Barcelona: Paidós, 1995.

Genette, Gerard. Métalepse: De la figure à la fiction. Paris: Éd. Du Seuil.

Gómez Tarín, Francisco Javier. “¿Quién narra en un film? Herencias teóricas, jerarquías e hibridaciones varias." SOPCOM, Lisboa, 14-15 April 2009. Conference paper.

Gómez Tarín, Francisco Javier. El análisis de textos audiovisuales: significación y sentido. Santander: Shangri-la Ediciones, 2010.

Hagener, Malte. "The Aesthetics of Displays: How the Split Screen Remediates Other Media," Refractory a Journal of Entertainment Media, 12 (2008): n. pag. Web. 24 Dec. 2008.

Kindt, Tom, and Müller, Hans-Harald. The implied author: concept and controversy. Berlin: Walter de Gruyter GmbH \& Co, 2006. 
Lipovetsky, Gilles and Serroy, Jean. La pantalla global: Cultura intermediática y cine en la era hipermoderna. Barcelona: Anagrama, 2009.

Loriguillo-López, Antonio and Sorolla-Romero, Teresa. "'Live, Die, Repeat': the blockbuster facing the interactive challenge," Fonseca, Journal of Communication 11 (2015): 118132.

Manovich, Lev. The Language Of New Media. Cambridge: MIT, 2001.

Ortega Martí, Marisol, García-Catalán, Shaila and Palao-Errando, José Antonio. "Raccord de doble hélice." Jornadas de Fomento de la Investigación de la Facultad de Ciencias Humanas y Sociales, Castellón, 10 December 2005. Conference paper.

Palao-Errando, José Antonio. 2008. “Corredores sin ventanas, acrobacias sin red: linealidad narrativa e imaginario hipertextual en el cine contemporáneo," Escrituras digitales: tecnologías de la creación en la era virtual, Virgilio Tortosa, ed. San Vicente del Raspeig: Publicaciones Universidad de Alicante, 2008: 289-312.

Palao-Errando, José Antonio. "El Telediario en el cine: una ventana abierta a un mundo cerrado." II Congreso Internacional de Teoría y Técnica de los Medios Audiovisuales: Tendencias del Periodismo Audiovisual en la Era del Espectáculo. Castellón de la Plana, 27-29 May 2009. Conference paper.

Palao-Errando, José Antonio. “Una escena en lo real, un axioma en lo simbólico, una frase en lo imaginario: la pantalla fílmica en Open Windows (Nacho Vigalondo, 2014),” Del Fotograma Al Byte Representaciones De Los Videojuegos En El Cine, Eduardo Guillot, ed. Valencia: Muvim, 2015: 99-118.

Poulaki, Maria. "Puzzled Hollywood and the return of complex films," Hollywood puzzle films, Warren Buckland, ed. London: Routledge, 2014: 35-54.

Quart, Allisa. "Happy Endings: The Post-Nuclear Family According to Don Ross," Film Comment, 41.4 (2005): 48-55. 
Ron, Moshe. "The Restricted Abyss: Nine Problems in the Theory of Mise en Abyme," Poetics Today, 8.2 (1987): 417-438.

Stam, Robert, Porton, Richard and Goldsmith, Leo. Keywords in Subversive Film/Media Aesthetics. Malden: Wiley Blackwell, 2015.

Sterritt, David. "Puzzle Pictures," Quarterly Review of Film and Video, 33.5 (2016): 478-481.

Tasker, Yvonne. "Sensation/investigation: crime television and the action aesthetic," New review of Film and Television Studies, 14.3 (2016): 304-323.

Thakkar, Amit. "Crash and Return: Choque, Allusion and Composite Structure in Alejandro González Iñárritu's Amores perros (2000)," Quarterly Review of Film and Video, 31.1 (2014): 11-26.

Thanouli, Eleftheria. Post-Classical Narration: A New Paradigm In Contemporary World Cinema. Amsterdam: Universiteit van Amsterdam, 2005.

Thompson, Kristin. Storytelling in the New Hollywood: Understanding Classical Narrative Technique. Cambridge: Harvard University Press, 1999. 